\title{
MOTIVÁLT ÉS MOTIVÁLATLAN TANULÓI ATTITŰD - ÉS AMI MÖGÖTTE VAN
}

\author{
BORSODI CSILLA NOÉMI \\ Komplex Alapprogram - Mérés-Értékelés Munkacsoport, Adatfelvételi Csoport
}

Jelen tanulmányában a szerző doktori disszertációjának néhány részeredményét mutatja be. Azt elemzi, hogyan interpretálják a különféle középiskola-típusok tanulói azon kihívásokat és nehézségeket, melyeket tanáraik említettek. Ilyen kihívás elsődlegesen a tanulói motiváció, illetve annak hiányának kérdése, melyet a pedagógusok a munkájukat leginkább nehezítő tényezőként említettek.

A vizsgálat fő eredményei között megemlíthető, hogy a diákok tanáraiktól elvárják, hogy a munkaerőpiacon jól hasznosítható, gyakorlatorientált ismereteket nyújtsanak, melyek hiányát kiemelt nehézségként, problémaként azonosítják. A szakképzésben tanulók esetén jelen elváráshoz társul a szakmai tantárgyak tanulásának megkönnyítése, a gimnáziumban pedig a továbbtanulás támogatása. Az ezekben mutatkozó hiányosságok, valamint a differenciálás hiánya hozzájárulhatnak a diákok motivációvesztéséhez, amely különösen a szakképzés esetén jelenthet veszélyt, mivel elősegítheti a korai iskolaelhagyás mértékének növekedését.

Megállapítható az is, hogy a könnyebb alkamazhatóság, gyakorlatba ültethetőség észlelése leginkább a tantárgyak népszerűségével függ össze, és nincs szoros összefüggés a tanár és a tantárgy népszerüsége között. A tanárokat általában jobban kedvelik a diákok, mint a tantárgyat, ugyanakkor a kedvező tanár-diák viszony nem garantálja minden kétséget kizáróan, hogy a tanuló örömmel tanulja a tantárgyat, és felkészül az órákra. Az érdemjeggyel való elégedettség fontossága csak a gimnáziumban jelenik meg. Érdemes ehhez hozzátenni, hogy a szakképzésben tanulók elégedettebbek a legkevésbé kedvelt tantárgy (átlag: 2,94, medián: 3, módusz: 3, szórás: 1,127) érdemjegyével, mint a tantárggyal, ugyanakkor a tanárral való elégedettségük kedvezőnek tekinthető (átlag: 3,59, medián 4, módusz: 5, szórás: 1,373). További érdekességként említendő az informatikaoktatás és az informatikatanár szerepe mint közismereti tantárgyat oktató tanár és a tantárgy kedveltségének összefüggése, mivel ez nem kötelező érettségi tantárgy, és láthatóan kevesebb lehetőség nyílik a módszertani sokszínűségre. A gimnáziumban „középmezőnybeliként” jelenik meg, azonban a szakképzésben a legnépszerűbb tantárgy (átlag 3,81, medián: 4, módusz: 5, szórás: 1,125). A tantárgy népszerüsége a legszorosabban a kellemes tantermi közérzettel $(\mathrm{r}=0,611 ; \mathrm{p}=0,000)$, a tanárral való kedvező viszonnyal $(\mathrm{r}=0,501 ; \mathrm{p}=0,000)$, a tanár kedvességével ( $\mathrm{r}=0,506 ; \mathrm{p}=0,000)$ való elégedettséggel függ össze, továbbá azzal, hogy érdekesnek ítélik az adott feladatokat $(\mathrm{r}=0,552 ; \mathrm{p}=0,000)$, úgy gondolják, segíti szakmai 
tárgyak elsajátítását $(\mathrm{r}=0,561 ; \mathrm{p}=0,000)$, továbbá úgy észlelik, a tanár segítókész $(\mathrm{r}=$ $0,510 ; \mathrm{p}=0,000)$. Összefoglalva, a tantárgy népszerűségének okai jellemzően az elvárások teljesülésének mértékéhez kapcsolódnak, amelyek összefüggenek a tanulók által is észlelt fejlesztő hatással, a gyakorltatorientáltsággal kapcsolatos elvárások teljesülésével, valamint a kedvező osztálytermi közérzettel.

\section{Bevezetés}

E tanulmányban a szerző 2020. november 19-én sikeresen megvédett disszertációjának néhány részeredményét mutatja be, mely eredetileg a középiskolai közismereti tantárgyakat oktató pedagógusi eredményességértelmezésre, eredményes pedagógusi munkára, valamint megvalósíthatóságának fó gátjaira, továbbá alapfeltételeire vonatkozó tanári és tanulói nézetek, hiedelmek fö legjellegzetesebb mintázatainak és összefüggéseinek intézménytípusfüggő feltárását célozza. Mindezekből azon elemeket mutatjuk be, melyek a pedagógusok által hivatkozott nehézségek - tanulói motiváltság biztosítása, tantárgyi attitűd javítása - mögött állnak. A pedagógusi vizsgálatok eredményeit mellőzve tehát kizárólag a tanulók körében lefolytatott kutatás fó tanulságait tárjuk fel, azonosítva azt, hogyan interpretálják a diákok a pedagógusok által felvetett - a tantárgyi attitűddel kapcsolatos negatív észlelésekre, tanulói motiválatlanságra vonatkozó - nehézségeket, kihívásokat.

\section{A középiskolások tanuláshoz való viszonyának elméleti háttere}

Munkánk következő részében a tanár, illetve a tanárgy kedveltségére mint a tanulási motivációt meghatározó lényeges tényezőkre vonatkozó szakirodalmi előzményekből adunk rövid ízelítőt.

\section{A tanár kedveltsége}

Említésre érdemes Szabó (1990) ma is aktuális munkája, aki azt találta, hogy a diákok jellemzően két kategóriában gondolkodnak a kedvelt tanár megítélésében. Ezek egyike „okos”, aki „föszerepében” tanár, nagy tudású, jól magyaráz, de meg is követeli, amit „leadott”, tehát helytáll a „tananyagleadó” pedagógusi szerepelvárások tekintetében, emellett jó kapcsolatot ápol diákjaival. A kérdezettek 39\%-a állította, hogy ez igaz kedvenc tanárára. Másik kategória a „kedves-okos”, nagy szaktantárgyi tudással rendelkező, autokratikus vonásoktól mentes pedagógus. A megkérdezettek 61\%-a jellemzi így utólag egykori pedagógusának percepcióját. A nem kedvelt tanár esetén szintén két típust talált a szerző. Egyik az „okos-gonosz” kategórianevet 
kapta, mivel jó tanítási képességekkel rendelkezik, azonban a kapcsolati faktorban alacsony értékelést kapott, ugyanis erősen autokratikus vonásai ezt vélhetően nehezítették. Másik kategória a „gonosz" tanár, akit alkalmatlannak tituláltak. Emberi gyengeségeit szaktudása sem ellensúlyozhatja. Nincs különbség oktatott tantárgy, azaz tantárgyi kedveltség szerint, sem a reál és humán tantárgyak tanárai között. A tantárgy jellege tehát Szabó vizsgálata szerint nem befolyásolja a tanár kedveltségét vagy elutasítottságát.

Eredményei nyomán vizsgáltuk, hogy a tantárgy kedveltsége összefüggésbe hozható-e a pedagógus kedveltségével, vagy egyéb tényezők dominálnak a tanulók pedagógusokat illető megítélésében. Munkánk következő részében a tantárgyi attitűd szerepét részletesen elemezzük.

\section{A tantárgy kedveltsége}

Több kutatás rámutat, hogy a középiskolában kedvelt tantárgy az, amiből a tanulók leginkább valószínű, hogy továbbtanulnak (Csapó, 2000; Csíkos, 2012), azonban a továbbtanulási szándék és a tantárgyi attitüd kapcsolata csupán 9. évfolyamig nő, utána visszaesik az idegen nyelv, majd ezt követően irodalom és történelem kivételével, melyek kedveltségének kapcsolata a továbbtanulási szándékkal töretlen marad. Egyéb kutatások kimutatták, hogy a diákok egyes tantárgyakhoz való viszonya középiskolás tanulmányaik során folyamatosan romlik, különösképpen a természettudományos tantárgyak, illetve a matematika esetében. (Csapó, 2000; 2002; Fernengel 2002) A tanuláshoz való viszonyra jellemző, hogy a magyar tanulók jellemzően nem bíznak képességeikben, nem értékelik megfelelően az elsajátított tudásukat (B. Németh-Habók 2006;). A természettudományos tárgyak közül kiemelt jelentőségü a fizika tantárgy tartósan rossz pozíciója a kedveltségi listán (Józsa 1999; Csapó 2002; Chrappán-Malmos, 2016).

Chrappán és Malmos (2016) a tantárgy kedveltségének alakulására gyakorolt hatásokat vizsgálta többek között a pedagógusok személyisége, az általuk alkalmazott tanítási módszerek, a rendelkezésre álló eszközök és a tanulási szokások és motiváló tényezők vonatkozásában. Azt találták, hogy a tantárgyak kedveltsége és a hasznosság észlelése (gyakorlatorientáltság, továbbtanulás szempontjából való hasznosíthatóság) között nincs szoros összefüggés. Különösen a matematikára igaz ez, melyet a szerzők által megkérdezett tanulók hasznosnak ítélnek, azonban nem kedvelik. Leginkább az idegen nyelvet érzik hasznosnak és kedvelik is a diákok. Csekély mértékben lemaradva követi ezt a magyar nyelv és irodalom, melynek hasznossága és kedveltsége azonos mértékủ. A szaktanár módszertani kultúrája is szoros összefüggést mutat a tantárgyi attitűddel (Mc Kinsey and Company, 2007; Chrappán-Malmos, 2016), lényeges tényező továbbá a tantárgy kedveltségének vonatkozásában a tananyag érdekességének észlelése is, azonban a gyakori dolgozatírás, illetve a rendszeres számonkérés nem mutat összefüggést a tantárgy kedveltségének alacsony 
szintjével. Az alacsony kedveltségi szinttel összefüggésbe hozható viszont a pedagógustól érkező jutalmazó, elismerő magatartás hiánya. (Chrappán-Malmos, 2016)

Vizsgálatunk elsődlegesen Chrappán és Malmos (2016) eredményeire támaszkodva tárta fel, vajon a tanulók esetében az általuk említett tényezők, pl. tanár kedveltsége, általa megvalósított módszertani sokrétűség, illetve a tantárgyak oktatásával kapcsolatos hasznosság, gyakorlatorientáltság érzetének mértéke összefügg-e a tantárgy kedveltségével.

\section{Az empirikus kutatás bemutatása}

Munkánk e részében vizsgálati eredményeink átfogó bemutatására vállalkozunk. Miután röviden szót ejtettünk a kutatás szakaszairól, módszereiről és mintáiról, fö eredményeinket prezentáljuk.

\section{A kutatás szakaszai, módszerei, mintái}

Az első tanulói kvantitatív vizsgálati fázis alanyai közé 124 gimnáziumi és ugyanennyi szakképzésben tanuló került. (Ebből $\mathrm{N}=72$ szakgimnazista és $\mathrm{N}=52$ szakközépiskolás). Az átfogó, tantárgyankénti, tantárgyi kedveltség összefüggéseinek eredményeit ellenőrző vizsgálat alanyai közé $\mathrm{N}=103$ gimnazista és $\mathrm{N}=118$ szakképzésben tanuló került (ebből $\mathrm{N}$ = 83 szakgimnazista és $\mathrm{N}$ = 35 szakközépiskolás). Mivel a kvantitatív vizsgálatok eredményeinek mélyebb, specifikusabb megértése volt a célunk, a kvalitatív kutatási fázis megvalósítása elengedhetetlen volt. Az írásbeli kikérdezés eszközének vizsgált területeit szerettük volna mélyebben elemezni, ugyanakkor félig-meddig mégis a kötetlen beszélgetés hangulatára törekedtünk, így a félig strukturált interjú módszerét választottuk, mivel leginkább ez az, ami mellett azáltal, hogy csak a feltétlenül érinteni kívánt kérdéseket és szempontokat adjuk meg, nyitottak maradhatunk a válaszadó feleleteire, gondolataira, és ennek megfelelően, a megadott tág keretek között folytathatjuk le az interjút. (Sántha, 2009)

Két Borsod-Abaúj-Zemplén megyei szakképzést végző intézményben folytattunk interjút, összesen 6 tanulócsoporttal. Az első helyszínen két egyéni tanulói mélyinterjút is lehetőségünk nyílt lefolytatni. Gimnáziumok esetében a tanulói interjúkba csupán egy borsod-abaúj-zempléni gimnázium egyezett bele, ahol két tanulócsoporttal volt lehetőségünk fókuszcsoportos interjút folytatni.

\section{A kutatás fó eredményei}

A következőkben a tantárgyi attitűd mint eredményességi kritérium fö összefüggéseit, valamint - mivel a pedagógusok leginkább a tanulók motivált magatartásának hiányosságaival küzdenek - a tanulási motiváció egyes megnyilvánulási formáinak jellemzőit mutatjuk be. 


\section{A tantárgy kedveltségének jellemzöi}

Tanulók körében lefolytatott kutatásunk során azt találtuk, hogy a pedagógust valamennyi esetben jobban kedvelik a diákok, mint a tantárgyat. A következő táblázatok a tantárgyi kedveltség leglényegesebb összefüggéseit mutatják be. Valamennyi esetben $p=0,000$.

\begin{tabular}{|l|l|l|}
\cline { 2 - 3 } \multicolumn{1}{l|}{} & $\begin{array}{l}\text { Matematika } \\
\text { (átlag 2,93) }\end{array}$ & $\begin{array}{l}\text { Fizika } \\
\text { (átlag 1,75) }\end{array}$ \\
\hline $\begin{array}{l}\text { Fontosnak érzem szakmai-szellemi fejlödésem } \\
\text { szempontjából. }\end{array}$ & $\mathrm{r}=0,412$ & $\mathrm{r}=0,734$ \\
\hline Gyakorlatias, későbbi munkám során hasznosítható. & $\mathrm{r}=0,414$ & $\mathrm{r}=0,681$ \\
\hline Jól érzem magam az órán. & $\mathrm{r}=0,564$ & $\mathrm{r}=0,683$ \\
\hline Jó a kapcsolatom a tanárral. & $\mathrm{r}=0,473$ & $\mathrm{r}=0,685$ \\
\hline A tanár rendszerint kedves velem. & $\mathrm{r}=0,494$ & $\mathrm{r}=0,718$ \\
\hline Jó eredményeim vannak a tantárgyból. & $\mathrm{r}=0,690$ & $\mathrm{r}=0,623$ \\
\hline $\begin{array}{l}\text { Segíti e tantárgy oktatása a továbbtanulásra való } \\
\text { felkészülésemet. }\end{array}$ & $\mathrm{r}=0,539$ & $\mathrm{r}=0,562$ \\
\hline Érdekesek a feladatok. & $\mathrm{r}=0,595$ & $\mathrm{r}=0,562$ \\
\hline Érdekel, amit ezeken az órákon tanulunk. & $\mathrm{r}=0,650$ & $\mathrm{r}=0,644$ \\
\hline A tanár igyekszik a jó tulajdonságaimat megismerni. & $\mathrm{r}=0,426$ & $\mathrm{r}=0,635$ \\
\hline Sokféle módszerrel tanít a tanár. & $\mathrm{r}=0,426$ & $\mathrm{r}=0,610$ \\
\hline $\begin{array}{l}\text { Olyan alaptudást ad, ami hozzásegít a sikeres } \\
\text { érettségihez. }\end{array}$ & $\mathrm{r}=0,522$ & $\mathrm{r}=0,763$ \\
\hline Magas színvonalon folyik az oktatás. & $\mathrm{r}=0,539$ & $\mathrm{r}=0,745$ \\
\hline dicséret, kis ötös/piros pont). & $\mathrm{r}=0,550$ & $\mathrm{r}=0,637$ \\
\hline
\end{tabular}

\section{1. táblázat. A második kvantitatív fázisban részt vett gimnáziumi tanulói minta} $(N=103)$ legkevésbé kedvelt tantárgy iránti attitüdjének fö összefüggései matematika tantárgy esetében $N=101$, fizika tantárgy esetében $N=51$ válasz alapján (saját szerk.)

Mivel a nem kedvelt tantárgyak összefüggéseit mutatja a 1. táblázat, így a fentiek azt jelzik, mindezen tényezők a kevésbé kedvelt tantárgyak esetében nem tünnek sikeresnek. Ezek azon tényezők, melyekről úgy látják, a tantárgy kedveltségét csökkentik. A gimnazisták körében leginkább kedvelt tantárgyak összefüggéseit a 2. táblázat illusztrálja. 


\begin{tabular}{|l|l|l|}
\cline { 2 - 3 } \multicolumn{1}{c|}{} & $\begin{array}{l}\text { Magyar nyelv és } \\
\text { irodalom }(3,61)\end{array}$ & $\begin{array}{l}\text { 1. idegen nyelv } \\
(3,56)\end{array}$ \\
\hline Magas színvonalon folyik az oktatás. & $\mathrm{r}=0,564$ & $\mathrm{r}=0,798$ \\
\hline Segíti a továbbtanulásra való felkészülésemet. & $\mathrm{r}=0,421$ & $\mathrm{r}=0,771$ \\
\hline Jó eredményeim vannak a tantárgyból. & $\mathrm{r}=0,583$ & $\mathrm{r}=0,770$ \\
\hline Érdekesek a feladatok. & $\mathrm{r}=0,538$ & $\mathrm{r}=0,734$ \\
\hline Jól érzem magam az órán. & $\mathrm{r}=0,609$ & $\mathrm{r}=0,734$ \\
\hline Elismerik a tudásomat. & $\mathrm{r}=0,525$ & $\mathrm{r}=0,736$ \\
\hline Le tudja kötni a figyelmemet. & $\mathrm{r}=0,484$ & $\mathrm{r}=0,710$ \\
\hline Fontosnak érzem szellemi fejlödésem szempontjából. & $\mathrm{r}=0,662$ & $\mathrm{r}=0,683$ \\
\hline Sokféle módszerrel tanít a tanár. & $\mathrm{r}=0,508$ & $\mathrm{r}=0,681$ \\
\hline
\end{tabular}

2. táblázat. A legkedveltebb magyar nyelv és irodalom, valamint az I. idegen nyelv tantárgyak összefüggései a második vizsgálati fázisban részt vett gimnáziumban tanulók ( $N=103)$ körében (saját szerk.)

Látható, hogy javarészt a szakképzésben is ugyanazon tényezőkkel a legerősebb az összefüggés, mint a gimnáziumban, tehát a nem kedvelt tantárgyra jellemző, hogy a tanár-diák kapcsolat egyes dimenzióival, valamint a tananyag hasznosságával nem elégedettek a diákok. (3. táblázat)

\begin{tabular}{|l|l|}
\cline { 2 - 2 } \multicolumn{1}{l|}{} & Matematika (2,37) \\
\hline Fontosnak érzem szakmai-szellemi fejlődésem szempontjából. & $\mathrm{r}=0,557$ \\
\hline A tanáromnak fontos, hogy jó eredményt érjek el. & $\mathrm{r}=0,550$ \\
\hline Jól érzem magam az órán. & $\mathrm{r}=0,532$ \\
\hline A tanár rendszerint kedves velem. & $\mathrm{r}=0,527$ \\
\hline Érdekesek a feladatok. & $\mathrm{r}=0,520$ \\
\hline Jó a kapcsolatom a tanárral. & $\mathrm{r}=0,501$ \\
\hline
\end{tabular}

3. táblázat. A legkevésbé kedvelt matematika tantárgy tanulói elvárások teljesülésére vonatkozó összefüggései a tantárgy kedveltségének mértékével a második vizsgálati fázisban részt vett szakképzésben tanulók mintája $(N=118)$ esetében (saját szerk.)

Mindezeknek megfelelően a legkedveltebb tantárgyak esetében hasonló tényezőkkel függ össze a tantárgy kedveltsége. (4. táblázat) 


\begin{tabular}{|l|l|l|l|}
\cline { 2 - 4 } \multicolumn{1}{l|}{} & Informatika (3,81) & $\begin{array}{l}\text { Magyar nyelv és } \\
\text { irodalom (3,49) }\end{array}$ & $\begin{array}{l}\text { 1. idegen nyelv } \\
(3,41)\end{array}$ \\
\hline Jól érzem magam ezeken az órákon. & $\mathrm{r}=0,611$ & $\mathrm{r}=0,601$ & $\mathrm{r}=0,530$ \\
\hline Érdekesek a feladatok. & $\mathrm{r}=0,552$ & $\mathrm{r}=0,584$ & $\mathrm{r}=0,527$ \\
\hline Le tudja kötni a figyelmemet. & $\mathrm{r}=0,428$ & $\mathrm{r}=0,548$ & $\mathrm{r}=0,401$ \\
\hline $\begin{array}{l}\text { Ha valamit nem tudok megcsinálni, } \\
\text { a tanár segít. }\end{array}$ & $\mathrm{r}=0,404$ & $\mathrm{r}=0,536$ & $\mathrm{r}=0,377$ \\
\hline $\begin{array}{l}\text { Számonkérés során a tanár az órán } \\
\text { elhangzottakat, az ott gyakoroltakat kéri } \\
\text { számon. }\end{array}$ & $\mathrm{r}=0,481$ & $\mathrm{r}=0,531$ & $\mathrm{r}=0,364$ \\
\hline Elismerik a tudásomat. & $\mathrm{r}=0,327$ & $\mathrm{r}=0,512$ & $\mathrm{r}=0,507$ \\
\hline Segíti a szakmai tantárgyak tanulását is. & $\mathrm{r}=0,561$ & $\mathrm{r}=0,501$ & $\mathrm{r}=0,423$ \\
\hline
\end{tabular}

4. táblázat. A legkedveltebb informatika, magyar nyelv és irodalom, valamint I. idegen nyelv tantárgyakban a tanulói elvárások teljesülésének összefüggései a tantárgy kedveltségének mértékével a második kvantitativ vizsgálati mintában részt vett szakképzésben tanulók $(N=118)$ esetében (saját szerk.)

A tantárgy kedveltsége - ami a leginkább könnyen megragadható és legkevesebb torzító hatást tartalmazó szubjektív teljesítményként jelent meg munkánkban - általában oktatásra vonatkozó kritériumokkal függ össze (hasznosság, munkaerőpiaci elvárásnak való megfelelés tanulói észlelése, továbbtanulást támogató funkció érdemi megvalósításának észlelése, ami a legérdekesebb, a szakképzésben is), lényeges tényező emellett a pedagógus módszertani sokrétűségével való elégedettség, azonban a kevésbé kedvelt tantárgyak esetén a tanár személyiségével, magaviseletével kapcsolatos jellemzők is megjelennek (következetes értékelés, tanár-diák kapcsolat jellege, erőssége, a pedagógus segítőkészsége).

Az érdemjegyekkel való elégedettség fontossága csak a gimnáziumban jelenik meg. Érdemes azonban hozzátenni, hogy a szakképzésben tanulók elégedettebbek a legkevésbé kedvelt tantárgyból elért érdemjegyükkel (átlag: 2,94, medián: 3, módusz: 3, szórás: 1,127), mint amennyire a tantárgyat kedvelik, és a tanárral való kapcsolatuk is inkább jónak tekinthető (átlag: 3,59, medián 4, módusz: 5, szórás: 1,373).

További érdekes adalékként jelenik meg az informatikaoktatás és az informatikatanár mint közismereti tantárgyat oktató tanár szerepe és tantárgya kedveltségének összefüggésrendszere, mivel nem kötelező érettségi tantárgy, és látszólag a módszertani sokrétüségre is kevesebb tér nyílik a tanár számára. Gimnáziumban „középmezőnybeliként” jelenik meg, azonban a szakképzésben a legkedveltebb tantárgy (átlag: 3,81, medián:4, módusz: 5, szórás: 1,125). A tantárgy kedveltsége a következőkkel függ legszorosabban össze: kellemes tanórai közérzet $(\mathrm{r}=0,611 ; \mathrm{p}=0,000)$, tanárral való kedvező kapcsolat $(\mathrm{r}=0,501 ; \mathrm{p}=0,000)$, a tanár 
kedvessége $(\mathrm{r}=0,506 ; \mathrm{p}=0,000)$; érdekes feladatok $(\mathrm{r}=0,552 ; \mathrm{p}=0,000)$, szakmai tárgyak tanulásának segítése $(r=0,561 ; p=0,000)$, tanári segítőkészség észlelése $(r=0,510 ; p=0,000)$. Természetesen a korábban a kedvelt tantárgyak esetében említett jellemzőkkel is fennáll az összefüggés, ám ezek nem annyira kiemelkedő erősségűek $(r<0,5)$, ugyanakkor hasonló mértékűek, mint az idegen nyelv esetében, mely kedveltség terén a szakképzésben „lemarad”, és a harmadik helyre csúszik. Az informatika tantárgyat jellemzően a tanár szeretteti meg, míg egyéb tantárgyak esetén a tartalom, maga a tantárgy az, amivel a diákoknak céljuk lehet.

Összegzésként kijelenthető tehát, hogy a tantárgy kedveltségének okai jellemzően az elvárások teljesülésének mértékével függnek össze, melyek az érzékelhető fejlesztő hatással, gyakorlatorientáltsággal, jövőképbe való illeszthetőséggel, továbbá a kedvező tanórai közérzettel kapcsolatosak.

\section{A tanulási motiváció egyes megnyilvánulási formáinak összefüggései}

A tanulók motiváltsága annak okán vált munkánk központi kérdésévé, hogy a pedagógusok mindennapi munkájuk eredményességét leginkább ettől teszik függővé. (Borsodi, 2020) 25 szakképzésben, 80 gimnáziumban tanuló vallja, hogy felkészül az általa leginkább kedvelt órákra. A nem kedvelt órákra szakképzésben 36, gimnáziumban 30 fó, az átlagosként definiált órákra szakképzésben és gimnáziumban egyaránt 42 fó készül fel, míg 35-en vallják a szakképzésben, hogy nem szeretnek felkészülni ezekre az órákra. Gimnáziumban e létszám mindössze $N=13$. A szakképzésben tanulók közül 18-an, míg a gimnáziumból szintén 18-an nyilatkoztak így a kedvelt, míg 23-an a szakképzésből és 60 -an a gimnazisták közül a nem kedvelt tantárgyak óráiról.

A tanárok azt állítják, hogy a tanulók motiválatlanok, azonban a tanulók egyértelműen rámutatnak, hogy mely tényezők okán nem szeretnek felkészülni egy adott órára. E tényezők közé tartozik szakképzésben a munkaerőpiaci hasznosíthatóság hiánya („általában vett” közismereti tantárgynál $\mathrm{r}=0,222, \mathrm{p}=0,000$, leginkább kedvelt tantárgynál $\mathrm{r}=0,257$; $\mathrm{p}=0,012$ ), a mindennapos számonkérés (nem kedvelt tantárgynál $\mathrm{r}=0,650 ; \mathrm{p}=0,000$; „általánosságban vett” tantárgynál $\mathrm{r}=0,321 ; \mathrm{p}=0,000$, leginkább kedvelt tantárgy esetén $\mathrm{r}=0,361 ; \mathrm{p}=0,000$ ), az unalmas tananyag (nem kedvelt tantárgynál $\mathrm{r}=0,445 ; \mathrm{p}=0,000$; általában a közismereti tantárgyak esetén $\mathrm{r}=0,377 ; \mathrm{p}=0,000$; leginkább kedvelt tantárgy esetén $\mathrm{r}=0,502 ; \mathrm{p}=0,000$ ), valamint az, ha a tanár olyasmiből írat dolgozatot, amiről nem tanultak (nem kedvelt tantárgynál $\mathrm{r}=0,340 ; \mathrm{p}=0,000$, általánosságban, a közismereti tantárgyak esetén $\mathrm{r}=0,271 ; \mathrm{p}=0,000$, leginkább kedvelt tantárgy esetén $\mathrm{r}=0,282 ; \mathrm{p}=$ 0,000). Interjús eredményeink közül két további aspektust is érdemes említeni, melyek egyike, hogy a pedagógusok a „fekete pedagógia” eszköztárával és szankciókkal „motiválnak”, másika pedig, hogy bár a pedagógus igyekszik, de drasztikus hátránnyal indul, mivel az általános iskolai kollégája már kedvét szegte a tanulónak. E tanulói vallomás alátámasztja, hogy 
az iskolához való viszony alakulásában - ahogy azt a Komplex Alapprogram szellemisége is diktálja - kiemelt szerepe van az általános iskolának és az ott dolgozó pedagógusoknak. Erre a következő, tanulói interjú során elhangzott idézet is utal:

"A tanár szerepe inkább általános iskolában, alsó tagozatban [fontos], ami nagyon lényeges az iskolában és a gyermekek jellemfejlödése és a tanulási kedvük meghozatala szempontjából, mert a tanáron múlik, hogy a gyermek szeret-e majd tanulni, vagy esetleg utálni fogja-e a tanulást, mint a sz.-t, tehát semmi pénzért nem fogja csinálni. Hát ez már felsöben is lényeges lehet, de nem annyira, mint alsó tagozatban, és gimnáziumban már végképp nem. A diák ekkor már rendelkezik olyan identitással, hogy el tudja dönteni, hogy szereti-e a tantárgyat, fontos-e ez neki, vagy hogy egyáltalán akar-e tanulni, és onnantól kezdve már csak az anyagot adja le a gyermeknek. Az, hogy nem úgy általában a tanulással kapcsolatban, hanem az adott tantárggyal kapcsolatban lehet ez kérdéses. Tehát lehet, hogy valaki annyira megutálja általános iskolában a történelmet, hogy aztán már teljesen mindegy, hogy mi történik vele felsöben vagy középiskolában, az úgy megmarad." (Tanulók 1. 1. tanulócsoport 1)

Gimnáziumban a tanulók legfőbb okokként a munkaerőpiaci hasznosíthatóság hiányát (nem kedvelt tantárgy esetén $\mathrm{r}=0,387 ; \mathrm{p}=0,000$; általánosságban vett közismereti tantárgyak esetén $\mathrm{r}=0,222 ; \mathrm{p}=0,000$; legkedveltebb közismereti tantárgy esetén $\mathrm{r}=0,483 ; \mathrm{p}$ $=0,000$ ), valamint az unalmas tananyagot jelölték meg (nem kedvelt tantárgy esetén $\mathrm{r}=$ 0,517; $\mathrm{p}=0,000$; általánosságban vett közismereti tárgyak vonatkozásában $\mathrm{r}=0,552 ; \mathrm{p}=$ $0,000$; leginkább kedvelt tantárgy esetén $\mathrm{r}=0,550 ; \mathrm{p}=0,000)$, továbbá azt, ha úgy érzik, a dolgozat nem a tananyagról szól, igaz, ez elsősorban a kedvelt tantárgy vonatkozásában kerül előtérbe $(r=0,483 ; \mathrm{p}=0,000)$. Ha tehát a dolgozat az általuk megismert, tanár által „leadott” tananyagról szól, szívesebben készülnek rá, mintha nem kapnak konkrét instrukciókat a tanulás szempontjairól.

Összegezve kijelenthető, hogy a tanulókkal nem egyeztetett kreatív gondolkodásra nevelés visszaüthet és a tanulási motivációt majdnem olyan mértékben csökkentheti, mint az adaptivitás hiánya vagy a mindennapos számonkérés okozta folyamatos stresszhelyzet.

Az is egyértelművé vált, hogy bár a tanulók elvárnak egyfajta „óraleadó” tanári attitűdöt, ám ezt inkább tekinthetjük negatív elvárásnak (ezek hiánya előtt állnak értetlenül), mivel a folyamatos szankcionálás olykor szintén „visszaüthet”, és rombolhatja a tanulói motivációt.

\section{A vizsgálat jelentősége, folytatási lehetőségei}

Eredményeinket egyfajta alapkutatásnak tekintjük a tanulói motiváltság javítását célzó pedagógiai innovációk megalapozásához, és hasznosíthatónak ítéljük azt az egyes intézmények minőségbiztosításának megvalósításában. 
Vizsgálatunk támogathatja hipotézisek megalkotását és mérőeszközök kidolgozását, amennyiben a Komplex Alapprogram középiskolai adaptációja vagy ahhoz hasonló fejlesztés bevezetésre kerül, hiszen eredményeink alapján megalapozottan feltételezzük, hogy a tanulók tantárgyhoz, illetve iskolához való viszonya státuszuk javítása által valósítható meg, így jelen mérőeszközök fejlesztése - különösképp a DFHT, illetve KIP bevezethetősége érdekében -, majd nagyobb mintán történő kipróbálása hasznos lenne a középiskolákban, különösképp azon intézményekben, melyekben a pedagógusok nagyfokú tanulói motiválatlanságról számolnak be, illetve ahol magas szintű a tanulók korai iskolaelhagyási tendenciája.

\section{Felhasznált irodalom:}

B. Németh, M. - Habók, A. (2006): A 13 és 17 éves tanulók viszonya a tanuláshoz. Magyar Pedagógia. Vol. 106 No. 2. pp.83-105.

Borsodi, Cs. N. (2020): A közismereti tantárgyakat oktató tanári eredményesség értelmezési lehetőségei az egyes középiskola-típusokban. Doktori (PhD) értekezés. Eger

Chrappán, M. - Malmos, E. (2016): Természettudományos attitűd vizsgálat egy pilot mérés tükrében. In: Educatio No. 4. pp. 608-616.

Csapó, B. (2000): A tantárgyakkal kapcsolatos attitűdök összefüggései. In: Magyar Pedagógia. Vol. 3. pp. 343-366.

Csapó, B. (2002): Iskolai osztályzatok, attitűdök, műveltség. In: Csapó, B. (szerk.): Az iskolai műveltség. Osiris Kiadó, Budapest. pp. 37-64.

Csíkos, Cs. (2012): Melyik a kedvenc tantárgyad? - Tantárgyi attitűdök vizsgálata a nyílt írásbeli kikérdezés módszerével. In: Iskolakultúra, No. 1. pp. 3-13.

Fernengel, A. (2000): A kémia tantárgy helyzete és fejlesztési feladatai. In: Új Pedagógiai Szemle. No. 9. pp. 68-82.

Józsa, K. (1999): Mi alakítja énértékelésünket fizikából? In: Iskolakultúra No. 10. pp. 72-80.

Mc Kinsey \& Company (2007): How the world's best school systems come out on top.

Sántha, K. (2009): Bevezetés a kvalitatív pedagógiai kutatás módszertanába. Eötvös József Kiadó, Budapest.

Szabó, É. (1999): A „kedves”, az „okos” és a „gonosz”, avagy a kedvelt és a nem kedvelt tanár képének jellemzői. Alkalmazott Pszichológia. 1. évf. 1.pp. 31-41. 